\title{
MUSEUMS AT BELLES-LETTRES: CULTURAL AND ECO- NOMICAL EFFECTS OF INDIRECT ADVERTISING
}

\begin{abstract}
Л.В. Прокопович. Музеї в художній літературі: культурно-економічний ефект непрямої реклами. Аналізується стан музейної галузі в умовах світової фінансової кризи. На конкретних прикладах доводиться ефективність такого виду реклами як product integration по відношенню до музеїв.

Ключові слова: музеї, фінансова криза, художня література, роман, реклама, маркетинг
\end{abstract}

Л.В. Прокопович. Музеи в художественной литературе: культурно-экономический эффект непрямой рекламы. Анализируется состояние музейной сферы в условиях мирового финансового кризиса. На конкретных примерах доказывается эффективность такого вида рекламы как product integration по отношению к музеям.

Ключевые слова: музеи, финансовый кризис, художественная литература, роман, реклама, маркетинг.

L.V. Prokopovich. Museums at belles-lettres: cultural and economical effects of indirect advertising. Analyzed is the museums' field condition under global economical crisis. Several examples investigated give evidences of high efficiency of "product integration" advertising type when considering the museums.

Keywords: museums, financial crisis, imaginative writing, advertising, marketing.

The global financial crisis has weakened numerous art-market segments, the museums' one inclusive. The largest museums of the world are forced to override the situation with the extreme measures; so, the British museum announced partial restriction of visitors' access to the expositions, which became accessible only to the fine art experts and special guests teams, ordering the payable excursions well in advance [1], the annual budget of Contemporary Art Museum in Leone (Spain) is half-shortened (compare the 10,6 mln. Euros in 2007 and 5,2 mln. Euros in 2013), with freezing the new chef-d-oeuvres purchases financing [2].

More and more often the museums' closing is announced: the examples being such as the globally known Museum of Geology at the Wyoming University, USA [3], the Guggenheim museum in Berlin, the Liechtenstein museum-palace in Vienna [4], the three archaeological sites in Cyprus remain out of visitors' access and the ancient Tamassos' excavation is stopped because of lack for both personnel and funds engaged [5].

At such critical background the Louvre museum situation seems to be incredibly successful: during the last five years namely this museum is the most visited one in the global scale. In 2012 the recorded visitors number increased up to 10 millions individuals (approx. one million increment when compared to the previous year) [6]. And its popularity is still steadily augmenting, which fact evidence being that in 2013 the Belgian customs officers removed 4 thousands of high-quality fake tickets for entrance to Louvre, produced in China [7].

The museum employees consider that such a success, besides of other factors, is due to the editorial success of Dan Brown's "Da Vinci Code", novel, which plot starts namely at the Louvre's locations. The book's fascinating plot and further cine-version served to an incredible interest both to the novel and its author as well as to the museum described therein.

An original tool for supporting such active interest has been invented by the museum: the visitors are proposed to follow the audio-guide (historic sites excursion conference read by Jean Renault, who played at the film the role of inspector Bezou Fache [8]. Thus, nowadays Dan Brown is considered as the founder of the whole tourists' industry, as in Paris there exist several tour itineraries called of the kind like "Following the Da Vinci Code's path". The guides are pleased to show the Ritz hotel, the Louvre, the Saint-Sulpice church. [9]. 
All that represent a clear illustration on how efficient can be the museum's indirect advertising (product-placement) through a popular book. And moreover, the given case is this one of specific product placement kind, so called the product integration.

Distinctively to product placement, the product integration correlates not only with simple occasional referring to the promoted product (should it be printed either cine-version of a popular book) but with such product's amalgamation with the artistic and imaginative tissue, its true integration into the scenario.

This method goes beyond the limits of "hidden", indirect advertising and event of every advertising kind because of two reasons: such approach is never perceived by the reader/spectator as an advertising as the "immediate proposal", aggression and compulsion typical for promo videos are absent here; from another side sometimes even the writer does' not perceive here the purposed advertising component; thus solving his target creative tasks the writer does rarely consider the possibility of byside promotional effects produces by his creation.

Meanwhile such effect does exist.

Another expressive example we can see as the readers of "The twelve chairs" novel by Il' $f$ and Petrov. One of the scene sites described refers to the Furniture Museum in Moscow, created in 1919 at the Girshman's villa, and, afterwards several reorganizations, closed in 1926.

Eight decades elapsed, the Furniture Museum in Moscow resurrected, but nowadays it is located at another building, in Taganka and certainly another exposition therein [10]. Still well aware of that the visitors never miss to ask "Is it just here the place where to did come Ostap Bender?" So the museum's promo events are often conceptualised with respect to the "Twelve chairs" novel's popularity.

Worth to mention is the fact that concurrently to some governmental museums' closing several new private ones are created.

So, in 2013 in the Odessa city a contraband museum started its activity. And there appeared even two the filibuster museums; in Yevpatoriya (Ukraine) and in Florida (USA), additionally to the previously established similar exhibitions in Santiago-de-Cuba, Cullera (Spain), Nassau (Bahamas) and other cities of the world.

But what stipulated namely this thematic area museums appearance? Eventually the huge massif of adventure and detective novels/cineversions devoted to those "entraining" activity and lifestyle?

Certainly the case sought above has no relation to product integration, but direct link between the museums' thematic field and popular literal basis is apparently manifested. Here takes place the same effect that served to creation of Sherlock Holms' museum: the Arthur Conan-Doyle writings' success inevitably led to the logic final of the celebre museum in London, Baker street $221 \mathrm{~b}$, opening.

In either case all the examples we considered have a meeting point: here the reciprocally oriented promotion takes place, when the book advertises a museum and vice versa. Considering the social role of literature and museums we should recognize that this marketing approach combines the characteristics of both commercial and social advertising thus strengthening both cultural institutes' positions.

The imaginative writings tools (distinctively to the official guides) allows the museum expositions "reviviscence", they are likely to leave their stands and go closer to the visitor, whose perception animates the images despite of strict warnings "please don't touch". The entraining books tend to partial compensation of newsworthiness deficiency usual for the museums, whose employees steadily positioning the museum as an art sanctuary are applying efforts to limit either even exclude the direct museumto-visitor communication; at the same time a worthy book renders the reader the feeling of involvement and interconnection not only with the museum exhibits but with the historic events related.

In such a way the museum staff could not only follow the novelties devoted to the museums' life but also maintain link with the authors composing their writings in related genres, to order customised literacy and even to act as literary agents.

Similar bilateral marketing would be especially promising for Odessa city cultural environment, where apart of numerous interesting and various museums there exist for a long time some original literary traditions having a particular very distinctive coloration.

Furthermore, the Odessa literature is strong not only with original traditions but with its readiness to novelties and creative experiments. When involved, the museums would reach the liveliness threshold, getting true revival and further development of their activity. 


\section{Literature}

1. В Британском музее беспрецедентный финансовый кризис [электронный ресурс] // NEWSru.com: Культура. — http://newsru.com.-23.05.2012.

2. Тихонова, Н. Как бюджетные проблемы ударили по культуре Старого и Нового Света [электронный ресурс] / Н. Тихонова // PROSTIR.MUSEUM. — http://prostir.museum./ua. — 14.10.2013.

3. Палеонтология и финансовый кризис: в США закрывают палеонтологический музей [электронный ресурс] // Аммонит.py. — http://www.ammonit.ru. — 30.06.2009.

4. Европа лишится двух известных музеев [электронный ресурс] // Дни.py. — http://www.dni.ru. 20.02.2012.

5. Музеи страдают от кризиса [электронный ресурс] // Вестник Кипра. — http://vkcyprus.com. 02.08.2013.

6. Парижский Лувр стал самым посещаемым музеем мира [электронный ресурс] // KM.ru. http://www.km.ru. - 21.12.2012.

7. Китайцы наштамповали фальшивых билетов на €144 тысячи [электронный ресурс] // Comments.UA. - http://comments.ua. - 12.09.2013.

8. Петрухина, Л. Брауновское движение: по следам “Кода да Винчи” [электронный ресурс] / Л. Петрухина // PARIZH.COM.UA. — http://www.parizh.com.ua. - 23.05.2006.

9. Дорогами Дэна Брауна, или по следам героев “Кода да Винчи” [электронный ресурс] // РИАновости. — http://ria.ru/tourism. - 22.06.2010.

10. Гацур, Г.Г. Музей мебели [электронный ресурс] / Г.Г. Гацур // История мебельного искусства и интерьеров. — http://www.mmmebl.ru. — 23.05.2012.

\section{References}

1. V Britanskom muzee bespretsedentnyy finansovyy krizis [The British Museum's unprecedented financial crisis] [electronic resource] // NEWSru.com: Kul'tura. — http://newsru.com. 23.05.2012.

2. Tihonova, N. Kak byudzhetnye problemy udarili po kul'ture Starogo i Novogo Sveta [As budget problems hit the culture of the Old and New Worlds] [electronic resource] / N. Tihonova // PROSTIR.MUSEUM. — http://prostir.museum./ua. - 14.10.2013.

3. Paleontologiya i finansovyy krizis: v SShA zakryvayut paleontologicheskiy muzey [Paleontology and financial crisis: Paleontological Museum in the USA is closed] [electronic resource] // Ammonit.ru. http://www.ammonit.ru. - 30.06.2009.

4. Evropa lishitsya dvukh izvestnykh muzeev [Europe will lose two famous museums] [electronic resource] // Dni.ru. — http://www.dni.ru. - 20.02.2012.

5. Muzei stradayut ot krizisa [Museums are affected by the crisis] [electronic resource] // Vestnik Kipra. http://vkcyprus.com. - 02.08.2013.

6. Parizhskiy Luvr stal samym poseshchaemym muzeem mira [Louvre in Paris has become the most visited museum in the world] [electronic resource] // KM.ru. — http://www.km.ru. — 21.12.2012.

7. Kitaytsy nashtampovali fal'shivykh biletov na $€ 144$ tysyachi [The Chinese have churned out counterfeit tickets for $€ 144,000$ ] [electronic resource] // Com-ments.UA. — http://comments.ua. — 12.09.2013.

8. Petruhina, L. Braunovskoe dvizhenie: po sledam "Koda da Vinchi" [Brownian motion: in the footsteps of "The Da Vinci Code"] [electronic resource] / L. Petruhina // PARIZH.COM.UA. http://www.parizh.com.ua. — 23.05.2006.

9. Dorogami Dena Brauna, ili po sledam geroev “Koda da Vinchi” [On Dan Brown's roads or in the footsteps of "Da Vinci Code" characters] [electronic resource] // RIAno-vosti. — http://ria.ru/tourism. 22.06.2010.

10. Gatsur, G.G. Muzey mebeli [Furniture Museum] [electronic resource] / G.G. Gatsur // Istoriya mebelnogo iskusstva i intererov [History of Furniture Art and Interiors]. - http://www.mmmebl.ru. 23.05.2012.

Reviever Dr. of Arts, Prof. of Odesa nat. polytechnic univ Bakanursky A.G. 